\title{
Recurrent cryptogenic stroke in young adult linked to congenital left ventricular diverticulum
}

Figure 1 Brain MRI showing both recurrent acute symptomatic and silent old infarctions within multiple territories

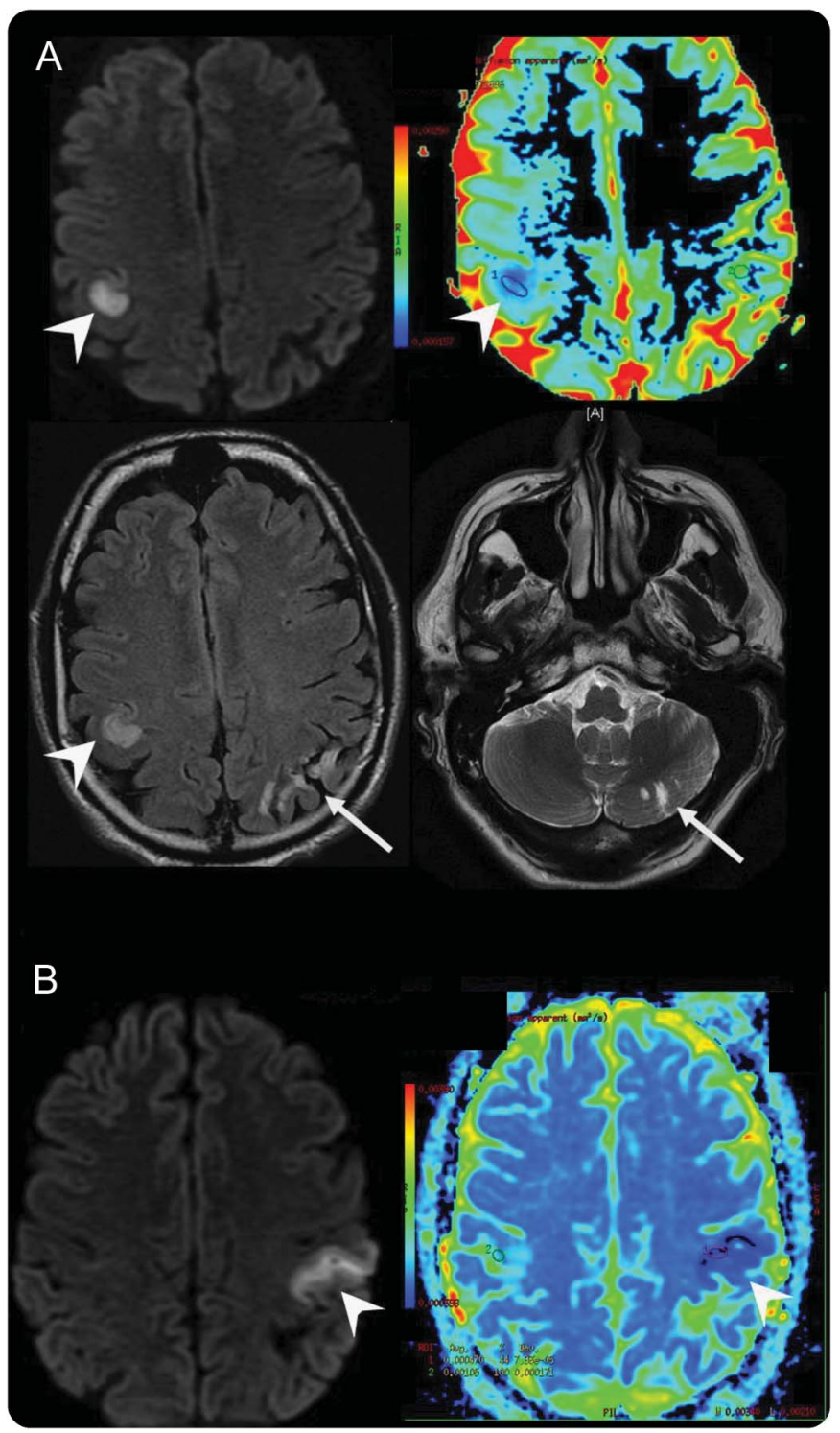

(A) DWI (left top), ADC color map (right top), and fluid-attenuated inversion recovery (left below) showing right rolandic acute infarction (arrowhead), and former silent infarctions within left middle cerebral and left posteroinferior cerebellar arteries (below, arrows). (B) DWI (left top) and ADC map showing second left rolandic acute infarction (arrowhead). ADC = apparent diffusion coefficient; DWI = diffusion-weighted imaging.

A 47-year-old man had an acute ischemic stroke (IS); brain MRI revealed multiple silent old IS (figure 1A). A comprehensive workup, including prolonged cardiac monitoring (cumulated duration of 25 days) and cardiac transthoracic/transesophageal echography, was negative. Eleven months later, despite statin and aspirin therapy, a new symptomatic embolic IS of undetermined source occurred (figure 1B). Cardiac MRI ${ }^{1}$ revealed a left apical dyskinetic saccular evagination (figure 2, A-C) consistent with a congenital left ventricular diverticulum 


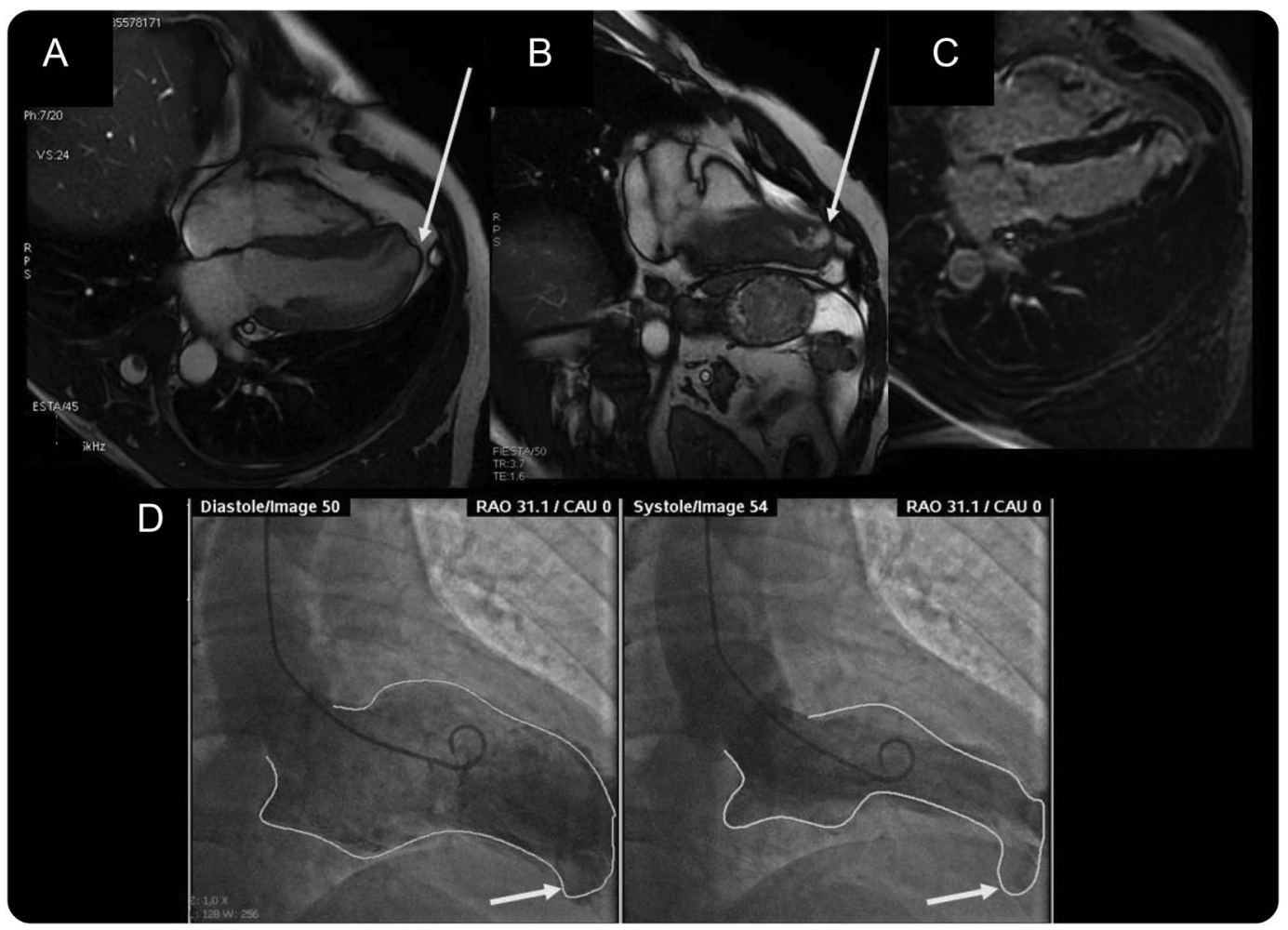

Cardiac MRI: (A) (diastolic phase 4-chamber plane) and (B) (systolic phase 2-chamber plane) showing apical ventricular dyskinetic saccular evagination consistent with LVD (arrows). (C) Delayed-enhancement cardiac magnetic resonance, 4-chamber view, postgadolinium-delayed image without enhancement of the diverticular and left ventricular walls. Left ventriculography (D) confirming LVD: diastolic (left) and systolic frame (right) showing contrast stagnation within hypokinetic apical evagination during cardiac systole (arrows). LVD = left ventricular diverticulum.

confirmed on left ventriculography (figure 2D) and the presumed source of recurrent embolic IS. ${ }^{2}$ No IS occurred after 30 months of warfarin therapy.

Nicolas Gaillard, MD, Frederic Targosz, MD, Jean Louis Bertrand, MD, Denis Sablot, MD, Zoubir Mourad Bensalah, MD

From the Services de Neurologie (N.G., D.S.), Cardiologie (F.T.), and Radiologie (J.L.B., Z.M.B.), Centre Hospitalier de Perpignan, France.

Author contributions: Dr. Nicolas Gaillard: study concept, design, acquisition of data, and writing of the manuscript. Dr. Frederic Targosz: acquisition and analysis of data. Dr. Jean Louis Bertrand: acquisition and analysis of data. Dr. Denis Sablot: acquisition and analysis of data. Dr. Zoubir Mourad Bensalah: acquisition and analysis of data, study supervision, and critical revision of the manuscript.

Study funding: No targeted funding reported.

Disclosure: The authors report no disclosures relevant to the manuscript. Go to Neurology.org for full disclosures.

Correspondence to Dr. Gaillard: nicola.gaillard@wanadoo.fr or n-gaillard@chu-montpellier.fr

1. Baher A, Mowla A, Kodali S, et al. Cardiac MRI improves identification of etiology of acute ischemic stroke. Cerebrovasc Dis 2014;37:277-284.

2. Ohlow MA, Secknus MA, Geller JC, von Korn H, Lauer B. Prevalence and outcome of congenital left ventricular aneurysms and diverticula in an adult population. Cardiology 2009;112:287-293. 


\section{Neurology}

\section{Recurrent cryptogenic stroke in young adult linked to congenital left ventricular diverticulum}

Nicolas Gaillard, Frederic Targosz, Jean Louis Bertrand, et al. Neurology 2016;87;2169-2170

DOI 10.1212/WNL.0000000000003341

\section{This information is current as of November 14, 2016}

\section{Updated Information \& Services}

References

Subspecialty Collections

Permissions \& Licensing

Reprints including high resolution figures, can be found at: http://n.neurology.org/content/87/20/2169.full

This article cites 2 articles, 0 of which you can access for free at: http://n.neurology.org/content/87/20/2169.full\#ref-list-1

This article, along with others on similar topics, appears in the following collection(s):

Cardiac

http://n.neurology.org/cgi/collection/cardiac

Embolism

http://n.neurology.org/cgi/collection/embolism

Infarction

http://n.neurology.org/cgi/collection/infarction

Stroke in young adults

http://n.neurology.org/cgi/collection/stroke_in_young_adults

Information about reproducing this article in parts (figures,tables) or in its entirety can be found online at:

http://www.neurology.org/about/about_the_journal\#permissions

Information about ordering reprints can be found online:

http://n.neurology.org/subscribers/advertise

Neurology ${ }^{\circledR}$ is the official journal of the American Academy of Neurology. Published continuously since 1951, it is now a weekly with 48 issues per year. Copyright (O 2016 American Academy of Neurology. All rights reserved. Print ISSN: 0028-3878. Online ISSN: 1526-632X.

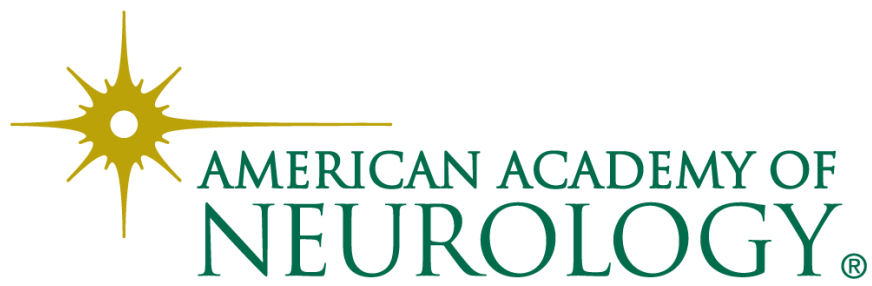

